\title{
A (IM)POTÊNCIA DA LINGUAGEM: SOBRE A DÚVIDA E 0 TESTEMUNHO DO INTELECTUAL (DE TOLSTÓI A TSÍPKIN)
}

Biagio D’Angelo'

ABstract: This paper aims at showing the ethics of the intellectual and his testimony as a responsibility in front of Literature and History. As a support for this hypothesis, we will analyze The Kreutzer Sonata, by L. Tolstoy, and Summer in Baden-Baden, by L. Tsípkin.

KEYworDs: Russian literature, Intellectual testimony, Language failure.

“В наш век, вы знаете, и слезы преступленье (...)

(...) Увы, моя глава

Безвременно падет: мой недозрелый гений Для славы не свершил возвышенных творений;

Я скоро весь умру. Но, тень мою любя,

Храните рукопись, о други, для себя!

Когда гроза пройдет, толпою суеверной Сбирайтесь иногда читать мой свиток верный, И, долго слушая, скажите: это он; Вот речь его." (Aleksandr Púchkin, “André Chenier”)

1 Professor Doutor de Teoria Literária e Literatura Comparada do Instituto de Romanística da Universidade Péter Pázmány, de Budapeste (Hungria).

2 "No nosso tempo, sabem, também as lágrimas são crime (...)/ Ai de mim, minha cabeça intempestivamente cairá: meu gênio imaturo / ainda para a glória obras sublimes não cumpriu; / irei logo morrer. Mas, se a minha sombra amares,/ guardai os manuscritos, amigos meus!/ Quando passar a tempestade, com a multidão ingênua,/ reuni-vos e lede o meu fidedigno pergaminho, / e, após ter escutado muito, dizei: é ele; / dele esse é o discurso (tradução minha). 


\section{Nostalgia do intelectual}

Será que a linguagem literária pode servir como paradigma da responsabilidade ética e pública do intelectual? Será que o intelectual, no espaço frágil e contraditório da literatura, pode como baluarte contra o discurso do Poder para - apesar de sua incoerência humana paradoxal - perpetuar a voz de um contra discurso que reescreve o mundo, sem censurar suas realidades "demasiado humanas"? A essas perguntas, que norteiam a reflexão dessas páginas, nos move um interesse, talvez nostálgico, para re-pensar e, talvez, re-avaliar - à luz da contemporaneidade - a figura e o valor do intelectual. De fato, hoje o papel do intelectual está em crise, resultado da "inactualidade do intelectual moderno” (SANTOS SILVA, 2004, p. 46): profético, solitário e censor. Izabel Margato e Renato Cordeiro Gomes se perguntam: “Torna-se ele (o intelectual) dispensável? Perdeu a razão de existir?” (Ibidem, 2004, p. 11). A discussão não se limita a uma especificidade da contemporaneidade ou da produção de literaturas periféricas ou pós-coloniais. Ao contrário, os textos que aqui serão levados em consideração (A Sonata a Kreutzer, de L. Tolstói, e Verão em Baden-Baden, de L. Tsípkin), distantes temporalmente, apresentam, ambos, a representação literária da figura do intelectual como elemento de convergência e de discussão: ou ele está num "túmulo", como quer Jean-François Lyotard, ou ele escolhe a faceta performática, como faz Umberto Eco. Haveria, então, uma terceira via?

Um juízo de Eduardo Prado Coelho nos ajuda a adentrar na nossa temática:

Não creio que os intelectuais tenham perdido a sua razão de existir. Mas penso que essa razão se flexibiliza hoje através de configurações inéditas que podem parecer inaceitáveis para os intelectuais de formação tradicional. "Eu já não sou desse mundo" - ouve-se dizer com frequência. Mas devemos contrapor-lhes a alegria sempre renovada de inventarmos um mundo e o desafio que consiste em continuarmos a pensar que temos um lugar e uma função nesse difícil e apaixonante trabalho de invenção (PRADO COELHO, 2004, p. 22, cursiva minha).

Esse "trabalho de invenção" permite observar o grau de embate entre o público e o privado, entre o posicionamento íntimo e o compromisso coletivo do intelectual-artista. Trata-se de um trabalho que, ao imaginar mundos paralelos, chega, nos textos ficcionais, até a invenção da verdade, como registra Derrida: 
Invenção significa ainda invenção da verdade no sentido do descobrimento que desvela o que se encontra já nela, mas que, também, é já invenção de outro tipo de verdade e de outro sentido da palavra "verdade" (DERRIDA, 1987, p. 84).

\section{André Chenier e os outros}

A figura do intelectual-poeta, do intelligent, como se denominou justamente a partir da experiência russa, nasceu e se consolidou tanto com a poesia dezembrista russa dos anos 20 do século XIX, quanto com a produção da poesia da plêiade puchkiniana. Pode-se dizer que, mais que em outras culturas, o poeta se identificou, na Rússia, com a responsabilidade civil e com uma presença viva na atividade político-cultural da época. Imitando Byron e Goethe, e seguindo os passos do espírito lúcido e revolucionário de Radíschev (cuja importante Ode à Liberdade foi escrita entre 1781 e 1783), poetas como Riléiev, Kiukhelbéker, Venevítinov, Baratínski e Viázemski sentiram a obrigação política como uma característica intrínseca e necessária à lírica e ao fazer literário.

Aleksandr Púchkin escreveu a elegia “André Chenier" em 1825, durante o exílio de Mikháilovskoie. É uma das poesias mais relevantes sobre o testemunho do intelectual, pois o ideal da independência do Poeta se entrelaça, por um lado, com a questão da missão, quase profética, do literato, e, por outro lado, com a ideia de uma liberdade social, fruto de uma liberdade individual procurada e desejada. A elegia de Púchkin é um verdadeiro hino à liberdade e é testemunha, modernamente, do olhar contraditório do poeta russo, que vê, no compromisso da Poesia, a única autêntica proposta de "revolução", no sentido de uma "evolução" espiritual de todo o povo. Todavia, apesar desse entusiasmo poético-político, o monólogo interior de André Chenier alerta o leitor e o homem de letras para a fragilidade da palavra, a insuficiência da linguagem como mudança utópica da sociedade e do sujeito. A única possibilidade de ser Poeta, afirma Púchkin nessa elegia, é se conceber ontologicamente como um indivíduo interiormente livre. Trata-se de um fundamento da weltaanschaaung romântica que, na atualidade, tem sido debatido pela aporia do significado da responsabilidade do intelectual. O J'accuse à sociedade que Púchkin transmite à posteridade, pela boca de André Chenier, consiste na negação da fratura entre o poeta e a multidão, entre a presumida superioridade do intelectual e a 
renúncia à cena da coletividade, entre a Beleza vivenciada como uma experiência superior, intimista, e a Palavra como riqueza frágil que é consciente da inconsistência de toda ação. "Guardai os manuscritos, amigos meus!", grita André Chenier no fragmento que citamos em epígrafe, consciente de sua última hora. Talvez, a impossibilidade de dizer a própria salvação ensine, no arquivamento dos manuscritos e dos discursos, a relembrar o que é morrer, corajosamente, na guilhotina.

\section{Um J'accuse erótico}

A experiência artística e humana de Tolstói parece dividir-se em duas trilhas que, embora resultem paralelas ao leitor, pela descontinuidade dos resultados, possuem, entre si, sutis canais dialógicos, que indicam um quase-desdobramento da personalidade do escritor russo. A partir dos anos 1879-80, Tolstói publicou Confissão, um texto autobiográfico (como foram, também, Infância e Adolescência, publicados entre 1852 e 1854) que representa a tendência tolstoiana de procurar uma própria educação interior, constantemente no limite entre o moralismo e a inquietude. Essa pedagogia excessiva do eu, que devia lhe vir das leituras profundas de Rousseau e dos "moralistas" franceses, desembocou, como se sabe, em crises espirituais frequentes. A escrita de Tolstói é a expressão de um trabalho angustiado e enérgico, à procura de uma objetividade real, sob o prisma do discurso literário, que responda aos problemas que afligem o sujeito. Prova dessa luta interior são, por exemplo, os capítulos de Anna Karenina (1878) em que Liévin raciocina e especula sobre o caráter da fé e a possibilidade de cinismo, deixada ao livre alvedrio. Nas páginas de Anna Karenina, a trama da heroína é sacrificada para uma meditação em primeira pessoa que corrói o discurso presumidamente objetivo do romance realista. Após a publicação de Anna Karenina, a crise religiosa de Tolstói agravou-se e o excessivo zelo pedagógico concretizou-se em um pensamento ideológico e doutrinário que produziu obras panfletárias como Crítica da teologia dogmática (1880), Sobre a vida (1887), O reino de Deus está dentro de vocês (1893) e, sobretudo, Que é a arte? (1897). Todavia, o impulso criativo não abandonou o autor de Guerra e Paz, mas sempre no limite da tendenciosidade e do artifício moralista, como se o 
campo estético fosse se transformado em uma arena de experimentalismo pedagógico, como sugere Ovsiániko-Kulikóvski. É nesse âmbito que surge a novela A sonata a Kreutzer (Крейцерова соната, 1889), uma das obras mais reconhecidas de Tolstói, escrita "com maldade", conforme a lembrança de Sofia Tolstáia. O tema desse romance breve é a oposição entre o amor carnal e a idealização e a pureza impossível dos afetos entre os sexos. A trama é bem conhecida: durante uma viagem de trem, Pózdnichev confessa, ao narrador em primeira pessoa do conto, o grave pecado que lhe mancha a alma: lembra ter apresentado à própria mulher um discreto violinista, famoso sedutor, só para provar a integridade moral da mulher. Tolstói insiste cinicamente sobre o clichê dos sentimentos elevados e da fidelidade conjugal que se inscrevem no modelo da mulher angelical. Atormentado pela dúvida e pela hipotética traição da mulher, Pózdnichev a assassina por ciúmes, por um adultério que, na realidade, nunca aconteceu, depois de ter visto os dois tocarem, em perfeita harmonia, a sonata para violino e piano de Beethoven, "A Kreutzer".

A sonata a Kreutzer, conto quase dostoievskiano na busca profunda dos elementos psicológicos que conduzem o sujeito a atuar e a utilizar a própria razão e liberdade, consiste em um violentíssimo j'accuse contra a sociedade moderna escravizada pelo sexo e pela opressão descomunal de pensamentos e imagens sexuais. Tolstói acredita ainda que a literatura possa funcionar como panfleto para o intelectual cumprir sua tarefa denunciadora e, talvez, moralizadora. Nesse sentido, o ciúme de Pózdnichev é mais cerebral que passional, e as explicações que ponteiam o texto tolstoiano são manifestações evidentes do conteúdo ideológico de seu autor. $\mathrm{O}$ amor carnal tem como resultado a morte das almas. É suficiente pensar nas duas chamativas epígrafes evangélicas que introduzem a atmosfera de perdição do relato, e na sua primeira parte, totalmente centrada no problema educativo, que pode ser resumido na expressão de um dos personagens: "as bobagens vêm da instrução".

O intelectual - parece-nos declarar Tolstói - possui o dom de preanunciar aos leitores os males da temporalidade. Os problemas devidos a uma sumária educação sexual e às mudanças repentinas da sociedade são as marcas intelectuais que formam essa novela paradigmática. Tolstói, de fato, quis abrir com essa obra o debate sobre o costume sexual moderno. Não é por acaso que as 
dificuldades dos jovens em relação às mulheres e ao amor encontraram eco em outras obras russas daquela época, como se a Sonata tolstoiana inaugurasse um zeitgeist temático perverso e mórbido. Já em Uma questão maldita (1904), Aleksei Gástev repropõe o mesmo conflito tolstoiano, entre o desejo de satisfazer o instinto sexual e a luta das razões para dominar as emoções, com a conviç̧ão de que só no diálogo recíproco podem ser vencidas as sombras das trevas. E também Aleksandr Kuprín, que de Tolstói era admirador, retomou a conversação sobre o sexo e as relações entre homem e mulher na obra O fosso (1909), que falava, pela primeira vez na literatura russa, da vida em um prostíbulo, assim como tinha já feito Guy de Maupassant em La Maison Tellier.

Contudo, algumas dessas obras hoje poderiam parecer excessivamente panfletárias, como a Sonata tolstoiana. Com efeito, Tolstói se disfarça em um papel de "juiz dos costumes". Sua percepção da figura do intelectual consiste em confiar demasiado na capacidade que a linguagem tem de poder revelar verdades e censurar vícios. Porém, se o intelectual tolstoiano é um profeta patético e fracassado, a Sonata possui outros elementos que resgatam esse texto do mero panfletarismo e indicam a posição do intelectual escritor.

A meu ver, a atualidade da nouvelle tolstoiana consiste em fatores que o intelectual põe em evidência, observando a capacidade da literatura de jogar com a linguagem. A Sonata tolstoiana metaforiza a incerteza da verdade da literatura e proclama a dúvida como o processo moderno que corrói as relações humanas, destruindo-as, a partir de seu interior, e corrompendo o olhar puro, ingênuo com que a realidade é percebida. Longe de ser uma acusação moralista, essa corrupção do Ser atinge mais precisamente a significação da linguagem literária. A essa corrupção do Ser corresponde o desfazer-se, nos termos de Michel Foucault, da "profunda pertença da linguagem e do mundo. Terminou a primazia da escrita. Desaparece, então, a capa uniforme na qual se entrecruzavam indefinidamente o visto e o lido, o visível e o enunciável. As palavras e as coisas vão se separando. O olho está destinado a ver e só a ver; a orelha só a ouvir. O discurso terá, desde então, como tarefa o dizer o que é, mas não será mais o que diz" (FOUCAULT, 1984, p. 50). Em outras palavras, entre as palavras e as coisas insere-se a suspeita sempre mais crescente de uma separação insolúvel, a de que a realidade do Outro está desesperadamente fora do alcance 
do Eu, e, consequentemente, a literatura não resolve o abismo do real, "espaço vão e fundamental", conforme as palavras de Foucault. "A escrita deixou de ser a prosa do mundo; as semelhanças e os signos têm roto seu velho compromisso; as similitudes enganam, levam à visão e ao delírio; as coisas permanecem obstinadamente em sua identidade irônica: não são mais o que são; as palavras vagam à aventura, sem conteúdo, sem semelhanças que as preencham; não marcam mais as coisas; dormem entre as folhas dos livros no meio da poeira" (Ibidem, p. 54). A dúvida se estabelece como marcador do devaneio do ser, enquanto a literatura só pode marcar a impotência da linguagem. $O$ intelectual escritor declara assim seu distanciamento da verdade, pois ele "sabe de não saber", ou de saber o pouco e a nada do Vazio.

A "história" da dúvida na literatura tem seu inicio magistral com a novela d'O Curioso impertinente, inserida no Quixote cervantino. É curioso observar que tanto Cervantes, quanto Tolstói escolhem um triângulo sentimental para relevar os perigos da dúvida, pondo em discussão a experiência de familiaridade com o real. ${ }^{3}$

Além disso, a suspeita e a dúvida carregam consigo morte e destruição. Assim como em Tolstói, também em Cervantes a mentira ficcional, o "fingido" que Cervantes continua reclamando do leitor, leva à extrema consequência, no discurso literário, o critério cartesiano da "dúvida metódica". Conforme Descartes, ao aceitar uma ideia clara e precisa, é muito fácil cair vítima de uma ilusão e, portanto, do engano. O filósofo francês aconselha, então, suspender o juízo e certificar-se da validade dos conteúdos da consciência: nessa "dúvida hiperbólica", que deveria eliminar toda suspeita de falsidade do

3 Retomando o exemplo medieval da história dos "dois amigos", de tradição oriental e inclusa no Decameron ("que puesto que aquello sea ficción poética, tiene en si encerrados secretos morales dignos de ser advertidos y entendidos e imitados", CERVANTES, 2005, pp. 335-6.), Anselmo, vítima de uma desnaturada curiosidade, pede ao seu melhor amigo, o "virtuoso e prudente" Lotário que corteje sua própria esposa Camila, para pôr à prova a fidelidade dela. No começo, Camila recusa, indignada, as pretensões do amigo do marido, deixando Anselmo feliz, mas insatisfeito: assim, decide que Lotário deve insistir até que Lotário e Camila se convertem em amantes, "protegidos" pela convição dé Anselmo, que ainda acredita nas virtudes dos dois. Mas a verdade é descoberta e Anselmo morre de dor. 
terreno existencial, instaura-se a função utópica e ilusória da "limpeza absoluta”. É esse desmoronamento de certa cultura cartesiana que a literatura se encarrega de desmascarar.

Com efeito, para recuperar um elemento de certeza absoluta, afirma Descartes, é preciso abandonar o conhecimento que se tem do mundo exterior, e "abandonar-se" à interioridade. Essa passagem da exterioridade à interioridade contra o "dado", o objetual, afastado em virtude de um subjetivismo perigoso e insinuante, parece a demonstração daquela atividade duvidosa que, pretendendo dar conformação ao sujeito temporal, ao mesmo tempo manipula-o e deixa-o nas mãos dos instintos repressores, como no caso de Pózdnichev. O duvidar, que já era um argumento tratado por Santo Agostinho, não representa mais uma inserção problemática no fenômeno do "dado", mas a verdadeira atividade pensante do sujeito, a intuição imediata da existência como pensamento.

É significativo ressaltar que, a partir da cultura do século XVI, no momento de máximo apogeu do homem, que se percebe dono de si mesmo e de uma explicação "suficiente" do universo, o intelectual passou a enfrentar a literatura para alimentar inquietudes, angústias, contradições. A linha em que a dúvida simboliza a ambiguidade do indivíduo, seu ser "nada", se comparado ao infinito, "um tudo em relação ao nada, um meio entre o nada e o tudo", como afirmaria Pascal, é também encontrável em manifestações estéticas das culturas orientais. ${ }^{4} \mathrm{~A}$ crise da inteligentsia eurocêntrica, que marca o abandono definitivo das concepções tradicionais monolíticas e fortemente dogmáticas, não é apenas prerrogativa da Europa do século XVI, mas investe, de forma prepotente, embora segundo bases e efeitos diversos, as culturas asiáticas, influenciadas pelo poder eurocêntrico e a ânsia de expansão mercantilista e colonizadora. Além disso, a profunda confiança na razão, inaugurada pela idade cartesiana, não apenas renuncia à metafísica como ciência de estudo e de sustento, mas insinua a autenticidade dos "pontos de vista": cada pers-

4 Referimo-nos, especialmente, à cultura e à literatura japonesas, que tipicamente caracterizaram-se por expressar, com profundo senso de pavor e maravilha, a precariedade da condição do homem, que deseja aspirar, por sua própria estrutura, à certezas sólidas e apoios seguros. 
pectiva diferente possui uma própria legitimidade, cada visão uma própria possibilidade de ser verdade. ${ }^{5}$

N’A Sonata a Kreutzer, Pózdnichev se reconhece como "corrupto na imaginação e na realidade" (cap. 4) e a sua impureza coincide com o afastamento do respeito do outro, uma depravação que vai mais além da sedução sexual ou do prazer do sofrimento sádico, em nome da própria autoafirmação.

A dúvida devasta a razão e os pensamentos de Pózdnichev, assim como atormentou Otelo com Desdêmona. E - assim como na obra de Shakespeare com A sonata a Kreutzer, o leitor não está frente a uma tragédia de ciúmes. Se o autêntico problema de Otelo tivesse sido o rancor ciumento para com Desdêmona, ele teria, em primeiro lugar, matado Cássio, assim como Pózdnichev deveria ter feito com Trukhatchévski. Mas o Otelo shakespeariano é o poderoso rei dos mouros que duvida da mulher, no momento em que Iago instila nele a suspeita da traição amorosa. Essa mesma dúvida é utilizada por Shakespeare alegoricamente. Em sua fraqueza humana Otelo tem uma única certeza: a pureza e a perfeição idealizada da mulher. Ela representa um universo virginal que nenhuma marca ou intervenção externa tinha maculado. Assim, a dúvida é sempre trágica porque revela a (in)existência de um espaço que responda aos desejos infinitos do sujeito. Ao personagem de Pózdnichev, como também ao Otelo shakespeariano, não importa o que aconteceu entre os dois supostos amantes. Importa-lhe, ao contrário, acreditar na dúvida - que lentamente vai penetrando, como uma doença, no uso da razão - e levar essa desconfiança a um processo de irracionalidade radical.

De Pózdnichev, que adota o seu ponto de vista como perspectiva parcial sobre os acontecimentos narrados, emerge uma escrita obscura, dentro de uma existência ainda incompleta e consciente das lacunas que a caracterizam.

5 Não é por acaso que, na palestra proferida durante a entrega do Prêmio Nobel 1994, o escritor japonês Kenzaburo Oe tenha se referido ao "ambíguo" como a característica de seu país: "a kind of chronic disease that has been prevalent throughout the modern age" (Kenzaburo Oe, website). Ambígua é a divisão abismal entre uma razão medida de todas as coisas, uma razão inventiva de cataclismos (como no caso de tristes invenções como a bomba atômica e de pavorosos delitos em nome de uma pureza como, alegoricamente, nos mostra Tolstói), e um humanismo que é o respeito do Outro em seus valores mais sagrados. 
Nesse sentido, o fragmento seguinte do escritor japonês Junichiro Tanizaki mostra como a literatura é um espaço de assombrações e não de revelações explicativas do real, enquanto o intelectual pode somente refugiar-se na profanação e na loucura:

Escrevo o diário porque o escrever me interessa. Não para que outros 0 leiam. Tendo a vista pavorosamente deteriorada não posso ler quanto e como gostaria. Não tenho outro modo de passar o tempo, e para encher esse vazio me vem continuamente o desejo de escrever. [...]

Os acontecimentos de há um ano me parecem completamente novos e lendo-os experimento um prazer infinito (TANIZAKI, 1987, p. 42).

\section{Um J'accuse ético}

Verão em Baden-Baden (Лето в Бадене), obra do russo Leonid Tsípkin, milagrosamente descoberta por Susan Sontag e brilhantemente traduzida para a língua portuguesa por Fátima Bianchi, é o outro texto que analisaremos brevemente nessas páginas. Trata-se de um romance "infinito", pela presença de um fluxo ininterrupto de frases, pensamentos, vozes, que raramente são quebrados por pontos e novos parágrafos. O texto denso e trágico se articula sobre as "questões malditas" que atormentam qualquer sujeito e às quais o intelectual tenta dar voz: "se pode viver sem Deus e sem fé?", "qual é o papel da arte na formação psicológica do sujeito?", "a linguagem pode dizer a verdade?", "o que ela pode representar eticamente?".

Esse romance, definido por Sontag, como "romance-sonho", e que é, como o fixa sugestivamente Elena Vengerskaya, "romance-agonia" (website), se desenvolve sobre os fios da memória: por um lado, o próprio Tsípkin "evoca sua

6 As relações sexuais vividas como antecâmara da dúvida existencial e, portanto, de uma corrupção dos afetos e da confiança que leva à autodestruição são magnificamente apresentadas nas obras- confissões de Junichiro Tanizaki, autor de romances como A chave, As irmãs Makioka e Diário de um velho louco. Em Tanizaki, a nostalgia de um olhar purificado se une à constante cegueira provocada pela dúvida e pela falsidade com que os personagens vivem o erótico. 
vida", e por outro, a vida de Fiódor Dostoiévski, relatada pelo autor "em uma narrativa torrencial e impetuosa" (SONTAG, 2003, p. 8). Em viagem para Leningrado, o eu narrador abre um livro, "cuja encadernação e cujo ex-libris ornamental são descritos carinhosamente" (Ibidem, p. 9). Trata-se do Diário, de Anna Grigórievna Dostoiévskaia, segunda mulher do escritor de Crime e castigo. Esse "diário" é o grande palimpsesto, o grande intertexto do romance de Tsípkin. O trabalho do "diário" é um exemplo marcadamente ficcional, apesar da verossimilhança dos fatos da realidade relatados. O escritor sabe que narrar não é reproduzir fielmente a vida, mas outorga uma ilusão de vida, de forma que o compromisso ético entre o fazer intelectual e a experiência subjetiva não esteja esvaziado de sentido. $O$ romance de Tsípkin apresenta aquela espiral de ficção e falsificação da realidade que constitui o processo inevitável da escrita, revelando todos os enganos do discurso autobiográfico:

Não somente a autobiografia pode mentir, mas a forma autobiográfica pode assumir a mais leve invenção romanesca: as "pseudomemórias", as narrativas "pseudo-autobiográficas" exploram a possibilidade de narrar em primeira pessoa uma história puramente imaginária (STAROBINSKI, 1970, p. 258).

No ato de desconstrução da identidade, que a estrutura da narrativa autobiográfica oferece, a escrita fragmentada - e "escravizada" pela repetição do quotidiano e do temporal - mostra soluções insuspeitadas ao problema da relação. Esse tipo de escrita memorialista se coloca dentro de

Um espaço diverso, alternativo e contraposto àquele do romance tradicional, capaz de submeter à dúvida e à revisão os critérios de identidade que caracterizam a tradição analítica a partir de Hobbes até Kant (MILDONIAN, 2001, pp. 33-4).

A narrativa dupla de Tsípkin, que oscila entre Leningrado, São Petersburgo, Dresden, e que lembra, como afirma Sontag, O mestre de São Petersburgo, de J. M. Coetzee, e Austerlitz, de W. G. Sebald, mistura elementos ficcionais com narrativas "reais". Se crônicas e autobiografias só reinventam o real, o escritor experimenta um momento paradigmático e vivencia um discurso privilegiado que interrompe a linearidade da memória: 
A continuidade do nosso corpo e das nossas funções cerebrais, como também a continuidade das lembranças, intenções e opiniões em qualquer perspectiva psicológica.

A gramática em primeira pessoa, que sustenta essa escrita, esvazia o eu de qualquer sério relacionamento consigo. Cada dia dizer eu significa introduzir uma entidade separada. Trata-se, na melhor das hipóteses, de uma sucessão de eus que apenas se conectam graças à retomada da escrita. [...]

No espaço restrito da página e no tempo sem retorno da jornada já consumada, o rosto e o nome se cancelam. Derruba a fé na identidade e a ela se substitui uma frágil ipseidade (Ibidem, p. 34).

Todavia, este romance de memória(s), que reconstrói a vida de um artista - como Artemísia, de Anna Banti, bem sublinhado por Sontag, é somente em um nível superficial o retrato de uma mulher pintora (Artemísia Gentileschi) no século de Caravaggio - é uma viagem alegórica rumo à morte e à ruína da realidade. Com efeito, os objetos e os sujeitos que fazem parte do jogo da Memória são reconhecidos graças à responsabilidade ética do Autor. É o Autor que deve relembrar a falência da linguagem e, portanto, das verdades carregadas pela literatura. Uma única possibilidade de salvação, se houver alguma, consiste no reconhecimento prodigioso de ser parecido e diferente dos sujeitos que nos precederam. Nesse sentido; é no diálogo com Dostoiévski que se embate o eu narrador de Verão em Baden-Baden. A reconstrução do passado torna-se assim um gesto de responsabilidade ética.

A ética do intelectual é, portanto, gritar a própria “ipseidade”, como afirma Paul Ricoeur. Para o filósofo francês, a “ipseidade” (1990, sobretudo, pp. 11-54 e pp. 199-236) é a capacidade do sujeito de se reconhecer, não como o mesmo, mas dentro das variantes e das variabilidades temporais. É um reconhecer-se, muito antes que um ser, que permite, particularmente, vislumbrar no eu as suas mais secretas andanças, as perpétuas transformações, as rupturas singulares e as dispersões que buscam uma resposta unitária. Ricœur declara justamente que a "ipseidade" salva, assim, o transitório e, ao mesmo tempo, põe em crise o passado, atualizando-o.

Estamos lendo o diário de Anna Grigórievna ou as memórias de Tsípkin? E por que chegamos a conceber uma imagem, fora dos estereótipos, de um 
Dostoiévski viciado, rebelde, violento e antissemita? Trata-se da possibilidade intrínseca da escrita diarística. N’O rumor da lingua, Roland Barthes escreve que o texto que se desprende da forma diarística é quase um resultado impossível, pois "é possibilíssimo que o Diário assim mantido não semelhe mais em nada a um Diário" (BARTHES, 1984, p. 382). O diário usa a elasticidade do rito quotidiano, garantindo-lhe uma veracidade "antipática" e "transgressiva". Quem busca a vida de um autor, encontra um homem, e, conforme o aforismo de La Bruyère, nisso consiste a decepção formal do diário.

A oscilação entre autor e homem, leitor cúmplice e leitor ingênuo, Texto e Diário, entre o objetivo e o subjetivo, confirma que a literatura se desloca em um "entre", isto é, move-se entre meios incertos, nos quais a realidade se dissimula por trás de uma máscara ficcional. A literatura propõe, portanto, um dispositivo, uma tekhné, que age segundo duas linhas ou tendências: por um lado, acentua a separação entre vida e ficção, por outro, engana com uma hegemonia da vida, em que a divisão precedente se vê reduzida, senão anulada. Quando a vida e a verdade estão harmonicamente próximas, não é preciso recorrer à escrita da Memória. Mas quando divergem, isto é, constantemente, num continuum inexorável, a narrativa torna-se, necessariamente, uma ficção autobiográfica. Nesse sentido, o romance de Tsípkin amplia a forma da crise do sujeito e da narrativa, da necessidade ética do intelectual e da literatura, e novamente, põe a dúvida sobre a possibilidade de conhecimento do Outro.

Verão em Baden-Baden é um diário especial, sobretudo se pensarmos que Anna Grigórievna era a "estenógrafa" dos textos de Dostoiévski, e que a escrita de Tsípkin, imitando o fluxo infinito - e não propriamente o estenográfico lembra o que Innokiénti Ánnenski dizia do estilo dostoievskiano: uma escrita "zakhlióbivaiuschaiassia” (uma escrita mal digerida). A escrita de Tsípkn é narcótica, sonambúlica, e imita a tentativa defeituosa da linguagem de penetrar, sempre com escasso sucesso, nas profundezas da existência. Trata-se de um mergulho profundo, inquieto e moderno, parecido à escrita sufocante e metamórfica de certos "diários", muito diversos entre eles, como o de André Gide com Le journal des faux-monnayeurs (1927) e o de Søren Kierkegaard de EnterEller (1843), em que se encontra o célebre Diário de urn sedutor. Nesse olhar retrospectivo a realidade se con-forma sobre duas vias aparentemente paralelas: 
por um lado, a incapacidade de ser escritor, eticamente perfeito (lembramos as páginas que Tsípkin, assumindo o discurso de Anna Grigórievna, dedica ao ví cio de Dostoiévski de jogar loucamente à roleta); por outro lado, a marca da linguagem que, apesar de sua falência, se instaura como processo órfico de testemunho sempre vivo e, ao mesmo tempo, transitório. O diário é, de fato, um gênero de testemunho, e, como sugere Dagnė Beržaitė:

O romance de Tsípkin é um testemunho pessoal e, também, epocal, no qual as recordações particulares e a recepção dos eventos, das pessoas, ordinários ou significativos pela triste realidade soviética, se confrontam, se medem com a interpretação autoral dos fatos da vida de Dostoiévski e da humanidade em geral (BERŽAITĖ, 2008, p. 56).

Tsípkin não escreve apenas um romance sobre o amor conjugal e a afeição sem limites de Anna Grigórievna pelo marido, ou, como afirma mais uma vez Susan Sontag, um texto que evidencia o amor pela Literatura como ato de conhecimento. Verão em Baden-Baden testemunha, ao contrário, o conhecimento da Morte e a incapacidade de salvação pela linguagem. Mas, ao mesmo tempo, esse romance se estabelece em um conjunto de textos (Lídia Guínzburg, Lev Razgón, Nadiéjda Mandelstam etc.) que, sobre as cinzas do legado stalinista e pós-stalinista, celebram a vida da escrita.

Assim são os inúmeros diários da época stalinista, os diários dos viajantes, dos presos, dos condenados à morte. Pode-se apreciar a intenção deles como memorialística e edificante; a posteridade deve lembrar o autor e o tempo e utilizar seu conhecimento para o aperfeiçoamento pessoal e dos outros (KÓRBIN, 2003, p. 290).

Lentamente a escrita de Tsípkin se metamorfoseia em um "j'accuse ético". De que ética se trata? É, no fundo, um movimento consciente de que a linguagem pode só indicar a morte como sentimento crucial da literatura. No romance há dois exemplos maravilhosos, ambos relacionados com a paixão de Dostoiévski pela pintura. Tanto na contemplação do "Cristo morto", de Halls 
Holbein, no "Kunstmuseum", de Basileia, quanto no êxtase vivido ao observar na Pinacoteca de Dresden a "Madona da Sistina", de Rafael, a morte ocupa um lugar privilegiado no romance, e a arte denuncia o testemunho da única verdade transmissível. Cravando os olhos na pintura de Holbein, "com uma intensidade renovada",

Ele [Dostoiévski] tornou a ver claramente o rosto e o corpo do Cristo morto e ouviu a frase sobre a perda da fé, dita por alguém - e essa ideia deveria tornar-se o centro do romance, e então objetos, cenas e imagens até então ainda imprecisos começaram a emergir da névoa (TSÍPKIN, 2003, p. 157).

Como relata Anna Grigórievna no Diário, o quadro preferido de Dostoiévski era a Madona da Sistina, de Rafael: "Muitos anos depois da viagem a Dresden, já bem pouco antes de sua morte, no dia de seu aniversário, Dostoiévski ganhou de presente uma reprodução desse quadro" (Ibidem, p. 31). A narração, porém, da vista do quadro em Dresden oscila entre a recordação de Anna Grigórievna e o sentimento experimentado por Dostoiévski, em um delírio geográfico, labiríntico, de Moscou a Dresden:

Eis a Madona da Sistina pendurada em um patamar entre dois andares, com um miliciano embaixo montando guarda - [...] a sinuosa fila de pessoas influentes ia se aproximando do quadro ou, mais exatamente, do vidro blindado atrás do qual, como se fosse um cadáver embalsamado num sarcófago, ficava o quadro com a madona e a paisagem de fundo, e o sorriso da madona era mesmo misterioso, mas isso talvez fosse apenas uma impressão sugerida por uma ideia corrente (Ibidem, pp. 30-1. Grifo meu).

Dizíamos que a arte denuncia o testemunho da única verdade transmissível, isto é, da morte que é considerada como uma experiência de silêncio, de contemplação e, no fundo, de ligação com uma vida misteriosa, fora do perceptível, do tangível. O cadáver embalsamado e o sorriso da Madona da Sistina se conectam também à morte do próprio Dostoiévski, descrita nas últimas páginas do romance com comovente emoção. Todavia, a verdadeira protagonista 
dessa morte é Anna Grigórievna - mais uma vez, o Autor do Diário - pois pensar nessa Passagem extrema se "reduz", na realidade, a um "não pensar": "A Morte é aquilo de que, na realidade, não podemos ter ou fazer experiência, em sentido tradicional, visto que o Trânsito fica intransitável pela nossa lógica, e incompreensível à razão" (FINAZZI-AGRÒ, 2006, p. 26).

A mulher ajoelhada, que era a própria personificação da dor, sentia sobre si a respiração desses estranhos que agora, por uma norma tacitamente aceita, mas uma norma inexorável, adquiriam direitos sobre seu marido [...] - nos vidros da janela do gabinete refletia-se a chama bruxuleante das duas velas sobre a escrivaninha, assim como a reprodução da Madona da Sistina flutuando nas nuvens com uma criança nos braços, pendurada sobre o sofá em que estava deitado o moribundo, e do lado de fora da janela jazia a noite de inverno de Petersburgo (TSÍPKIN, 2003, pp. 199-200).

\section{Demasiado humano (conclusões)}

Tanto o texto de Tolstói, quanto o romance de Tsípkin denunciam a impossibilidade de a linguagem fornecer um ponto de apoio para a resolução de dúvidas morais, de interpretações, ou de questionamentos ligados à fé e às perguntas últimas da existência. Escolhendo formas e gêneros liminares como diários, memórias e panfletos filosóficos, ambos os autores inserem nos textos uma fala subjetiva que é, por sua natureza, incompleta e imparcial, insuficiente e carente. A lógica por eles utilizada manipula a escrita romanesca ef faz parecer como não fictício o fictício, e como real o verossimilhante. A literatura se desencaixa, assim, do molde banalmente realista e se abre a uma superabundância de humanidade, posto que revela a responsabilidade da experiência nos processos da escrita. Aqui se torna valioso o testemunho do intelectual, sua atualidade, sua indispensabilidade. Com efeito, as dicotomias de intelecto e sentimento, de razão e intuição, de vida e morte são debilitadas a favor da dimensão atemporal do discurso narrativo. Aprofundar a negatividade da existência e procurar uma saída para o vazio do infinito é uma crítica às estruturas já estabelecidas. Se a vida quotidiana está ainda submersa no não senso, nas dores e nas tragédias existenciais, o intelectual testemunha a autenticidade da 
literatura que, imitando a vida, recusa sua finitude e, mostrando a corrosão de coisas, seres e temporalidades, incita a superar as vaidades e as contradições que o texto assimila naturalmente. Daí, as digressões e a aparente desordem das narrações que apresentamos, modelos precários que desestabilizam a narrativa, o relato íntimo, exaltando as dúvidas e as incertezas do Autor. Qualquer que seja a solução, o intelectual está chamado à invenção de uma ficção que desperte a experiência do sujeito e responsabilize a si mesmo e aos outros. Assim, parafraseando a citação de Púchkin em epígrafe, será possível que "no nosso tempo as lágrimas" já não sejam vistas como "crime”, mas como consciência trágica do testemunho.

\section{Referências bibliográficas}

BARTHES, Roland. Le bruissement de la langue. Essais critiques IV. Paris: Seuil, 1984. BERŽAITĖ, Dagnè. "O literature e liubvi (L. Tsípkin. Leto v Badene)". In: Literatūra. Revista da Universidade de Vilnius, n. 50 (2), pp. 53-63.

CERVANTES, Miguel de. Don Quijote de la Mancha. Madrid: Real Academia de la Lengua, 2005.

DERRIDA, Jacques. "Psyche: invenciones del otro". In: Block de Behar, Lisa (ed.), Diseminario. La desconstrucción. Otro descubrimiento de América. Montevideo: XYZ editores, 1987, pp. 49-106.

FINAZZI-AGRÒ, Ettore. "A voz de quem morre. O indício e a testemunha em Meu tio Iauraretê". In: O eixo e a roda. Belo Horizonte: Editora UFMG. Vol. 12, 2006, p. 25-32. FOUCAULT, Michel. Las palabras y las cosas. Una arqueología de las ciencias humanas. Barcelona: Planeta, 1984.

KORBIN, Kirill. "Pokhvala dnevniku" (Elogio do diário). In: Novoe literaturnoe obozrenie, n. 61 (2003), pp. 288-95.

MILDONIAN, Paola. Alterego. Racconti in forma di diario tra Ottocento e Novecento. Venezia: Marsilio, 2001.

OE, Kenzaburo. Japan, the Ambiguous, and Myself, Nobel Lecture, December 7, 1994. $<$ http://nobelprize.org/nobel_prizes/literature/laureates/1994/oe-lecture.html>. Acesso ao site 20 de junho de 2009. 
PRADO COELHO, Eduardo. "Novas configurações da função intelectual". In: MARGATO, Izabel - Cordeiro Gomes, Renato. O papel do intelectual hoje. Belo Horizonte: Editora UFMG, 2004, pp. 13-22.

RICCEUR, Paul. Soi-même comme un autre. Paris: Seuil, 1990.

SANTOS SILVA, Augusto "Podemos dispensar os inteletuais?". In: MARGATO, Izabel - Cordeiro Gomes, Renato. O papel do intelectual hoje. Belo Horizonte: Editora UFMG, 2004, pp. 39-67.

SONTAG, Susan. “Amar Dostoiévski”. In: TSÍPKIN, Leonid. Verão em Baden-Baden. São Paulo: Companhia das Letras, 2003, pp. 5-20.

STAROBINSKI, Jean. "Le style de l'autobiographie”. In: Poétique, n. 3, 1970, pp. 257-65. TANIZAKI, Junichiro. Fūten rōjin nikki (Diário de um velho louco). Milão: Bompiani, 1987.

TOLSTÓI, Lev. A Sonata a Kreutzer. São Paulo: Editora 34, 2007.

TSÍPKIN, Leonid. Verão em Baden-Baden. São Paulo: Companhia das Letras, 2003. VENGERSKAYA, Elena. "Recensia o knige Leto v Badene, NLO 2003”. Disponível na web. In: Nastoyashaya literatura. <http://www.litwomen.ru/print.html?id=877>. Acesso efetuado: 20 de julho de 2009. 